\title{
Drought impact in the Bolivian Altiplano agriculture associated with the El Niño-Southern Oscillation using satellite imagery data
}

\author{
Claudia Canedo-Rosso ${ }^{1,2}$, Stefan Hochrainer-Stigler ${ }^{3}$, Georg Pflug ${ }^{3,4}$, Bruno Condori ${ }^{5}$, and Ronny Berndtsson ${ }^{1,6}$ \\ ${ }^{1}$ Division of Water Resources Engineering, Lund University, P.O. Box 118, 22100 Lund, Sweden \\ ${ }^{2}$ Instituto de Hidráulica e Hidrología, Universidad Mayor de San Andrés, Cotacota 30, La Paz, Bolivia \\ ${ }^{3}$ International Institute for Applied Systems Analysis (IIASA), Schlossplatz 1, 2361 Laxenburg, Austria \\ ${ }^{4}$ Institute of Statistics and Operations Research, Faculty of Economics, University of Vienna, \\ Oskar-Morgenstern-Platz 1, 1090 Vienna, Austria \\ ${ }^{5}$ Inter-American Institute for Cooperation on Agriculture (IICA), Defensores del Chaco 1997, La Paz, Bolivia \\ ${ }^{6}$ Center for Middle Eastern Studies, Lund University, P.O. Box 201, 22100 Lund, Sweden
}

Correspondence: Claudia Canedo-Rosso (canedo.clau@gmail.com)

Received: 26 December 2018 - Discussion started: 27 March 2019

Revised: 11 October 2020 - Accepted: 14 January 2021 - Published: 15 March 2021

\begin{abstract}
Drought is a major natural hazard in the Bolivian Altiplano that causes large agricultural losses. However, the drought effect on agriculture varies largely on a local scale due to diverse factors such as climatological and hydrological conditions, sensitivity of crop yield to water stress, and crop phenological stage among others. To improve the knowledge of drought impact on agriculture, this study aims to classify drought severity using vegetation and land surface temperature data, analyse the relationship between drought and climate anomalies, and examine the spatio-temporal variability of drought using vegetation and climate data. Empirical data for drought assessment purposes in this area are scarce and spatially unevenly distributed. Due to these limitations we used vegetation, land surface temperature (LST), precipitation derived from satellite imagery, and gridded air temperature data products. Initially, we tested the performance of satellite precipitation and gridded air temperature data on a local level. Then, the normalized difference vegetation index (NDVI) and LST were used to classify drought events associated with past El Niño-Southern Oscillation (ENSO) phases. It was found that the most severe drought events generally occur during a positive ENSO phase (El Niño years). In addition, we found that a decrease in vegetation is mainly driven by low precipitation and high temperature, and we identified areas where agricultural losses will be most pronounced under such conditions. The results show that droughts can be monitored using satellite imagery data when ground data
\end{abstract}

are scarce or of poor data quality. The results can be especially beneficial for emergency response operations and for enabling a proactive approach to disaster risk management against droughts.

\section{Introduction}

Agricultural production is highly sensitive to weather extremes, including droughts and heat waves. Losses due to such hazard events pose a significant challenge to farmers as well as governments worldwide (UNISDR, 2009, 2015). Worryingly, the scientific community predicts an amplification of these negative impacts due to future climate change (IPCC, 2013). Especially in developing countries such as Bolivia, drought is a major natural hazard, and Bolivia has experienced large socio-economic losses in the past due to such events (UNDP, 2011; Garcia and Alavi, 2018). However, the impacts vary on a seasonal and annual timescale, in regards to the hazard intensity, as well as the existing capacity to prevent and respond to droughts (UNISDR, 2009, 2015). Regarding the former, the El Niño-Southern Oscillation (ENSO) plays an especially important role in several regions of the world, including the Bolivian Altiplano, as it drives drought occurrence that could cause losses of agricultural crops and increase food insecurity (Kogan and Guo, 2017). The most important rainfed crops in the region include 
quinoa and potato (Garcia et al., 2007). Generally speaking, agricultural productivity in the Bolivian Altiplano is low due to adverse weather and poor soil conditions (Garcia et al., 2003). On the other hand, low agricultural production levels can also be associated with ENSO (Buxton et al., 2013).

The ENSO is a climate phenomenon that affects the precipitation variability of the Bolivian Altiplano (Thompson et al., 1984; Aceituno, 1988; Vuille, 1999). The ENSO is defined as a periodical variation of the sea surface temperature over the tropical Pacific Ocean, and it represents neutral, warm (El Niño), and cold (La Niña) phases. The positive phase of ENSO is generally associated with warmer and dryer conditions, while the negative phase is associated with cooling and wetter conditions (Garreaud and Aceituno, 2001; Garreaud et al., 2003; Thibeault et al., 2012). Thus, droughts are generally driven by the positive ENSO phase in the study area (Thompson et al., 1984; Garreaud and Aceituno, 2001; Vicente-Serrano et al., 2015). Previous research has addressed the influence of ENSO on agriculture in South America and the globe (see Iizumi et al., 2014; RamirezRodrigues et al., 2014; Anderson et al., 2017). These studies were calling for a better understanding of the association between ENSO and agriculture to improve crop management practices and food security. However, predicting the ENSO effects is challenging, since the ENSO evolution depends not only on the tropic Pacific Ocean temperature, but also on atmospheric convection, climate variability, and teleconnection with other climate anomalies (Santoso et al., 2019).

The implementation of drought risk management approaches is now seen as fundamental (see e.g. the Sustainable Development Goals or the Sendai Framework for Risk Reduction) for sustainable development in vulnerable regions, including Latin American countries such as Bolivia (Verbist et al., 2016). To lessen the long-term impacts of these extreme events, the national government in Bolivia has taken several steps, e.g. to allocate budgets for emergency operations to compensate for part of the losses incurred. Most of these measures are implemented ex post (i.e. after a disaster event). However, based on ENSO forecasting, an El Niño event can be predicted 1 to 7 months ahead (Tippett et al., 2012), and consequently there is an opportunity to implement additional ex ante policies (i.e. before the event) to reduce societal impacts of droughts, increase preparedness, and generally improve current risk management strategies.

We embed our research within the IPCC framework (IPCC, 2012) and conceptually define disaster risk as a function of the hazard, exposure, and vulnerability. Here, drought risk was defined as the likelihood of severe alterations in the normal functioning due to drought hazard interacting with the vulnerabilities of the exposed socio-environmental system, leading to potential adverse effects. Furthermore, disaster risk usually comprises different types of potential losses, which are sometimes very difficult to quantify (UNISDR, 2009). In the case of drought, usually four different types are distinguished (UNISDR, 2009): meteorological, hydro- logical, agricultural, and socio-economic droughts. In more detail, a meteorological drought manifests if certain climate variables (e.g. precipitation) remain under predefined threshold levels over a certain time period, while hydrological drought is usually determined through reduced water levels in water bodies and groundwater. Agricultural drought occurs when insufficient soil moisture and precipitation negatively affect crop yields, while agricultural drought may turn into socio-economic drought if the supply or demand of agricultural products is negatively affected (see Wilhite and Glantz, 1985).

Using these concepts and definitions our research aims to (1) classify agricultural drought severity by applying the normalized difference vegetation index (NDVI; as a proxy for crop yields), land surface temperature data, and climate data (as the hazard component); (2) analyse the relationship between drought and ENSO; and (3) assess drought through examining the spatio-temporal variability of vegetation and its association with climate data (implicitly including the vulnerability component through the spatio-temporal variability). One major constraint for drought risk management in Bolivia is the scarce and uneven distribution of weather- and agricultural-production-related ground data. To circumvent this problem, we test satellite-based and gridded data products (compared to available empirically gauged data) to provide a full coverage (in respect to land area) for drought assessment and its spatial distribution across the region. Due to the particular importance of ENSO for drought risk management, we additionally assess the impacts associated with ENSO on agriculture for the Bolivian Altiplano. Furthermore, we give indications regarding which climate variables may be most important in which regions to predict drought losses that can further be used for hotspot selection. The paper is organized as follows, Sect. 2 provides a discussion of the data used, Sect. 3 present the methodology applied, Sect. 4 presents the corresponding results found, and Sect. 5 ends with a conclusion and outlook for the future.

\section{Data Used}

\subsection{Climate data}

Our methodology is very much related to the data-scarce situation for the Bolivian Altiplano, and we therefore start with an introduction of the available datasets that were used for our purpose. In regards to the climate dimension, the Altiplano has a pronounced southwest-northeast precipitation gradient (200-900 $\mathrm{mm} \mathrm{yr}^{-1}$ ) during the wet season occurring from November to March (Garreaud et al., 2003). Over $70 \%$ of total precipitation occurs during the summer months (from December to February; see Fig. 1a) in association with the South American Monsoon (see Zhou and Lau, 1998; Garreaud et al., 2003). Time series of monthly precipitation at 12 locations as well as mean, maximum, and minimum tem- 
perature at 8 locations from September 1981 to August 2015 were available from the National Service of Meteorology and Hydrology (SENAMHI) of Bolivia (see Appendix Table A1). These datasets had less than $10 \%$ of missing data and therefore served well for our analysis.

As already indicated, precipitation and temperature gauge locations are unevenly distributed and mainly concentrated in the northern Bolivian Altiplano. To improve the spatial coverage of climate-related data, monthly quasi-rainfall time series from satellite data the Climate Hazards Group InfraRed Precipitation with Station data (CHIRPS) were included in our study. CHIRPS represents a $0.05^{\circ}$ spatial resolution satellite imagery and a quasi-global rainfall dataset from 1981 to the near present (Funk et al., 2015). The advantage of using CHIRPS is the high spatial resolution of data, obtained with resampling of TMPA 3B42 (with a $0.25^{\circ}$ grid cell). The spatial resolution represents a better option for agricultural studies as well and therefore is most appropriate for our approach (CHIRPS is described in detail at https://www.chc.ucsb.edu/data/chirps, last access: 22 February 2021).

Additionally, a gridded dataset of monthly mean air temperature was obtained from the Physical Sciences Division (PSD) of the US National Oceanic and Atmospheric Administration (NOAA, https://www.esrl.noaa.gov/psd/, last access: 1 May 2020) defined by Willmott and Matsuura, using a spatial interpolation of composite stations records from the Global Historical Climatology Network (GHCN version 2) and Legates and Willmott (Legates and Willmott, 1990a; Legates and Willmott, 1990b). The gridded air temperature dataset has a resolution of $0.5^{\circ}$ by $0.5^{\circ}$ and was available during the study period from September 1981 to August 2015. This dataset incorporates station-height information through an average air temperature lapse rate (Willmott and Matsuura, 1995). Here, a digital elevation model was used for the interpolation to adjust air temperatures in relation to sea level.

\subsection{Land surface data: vegetation and temperature}

Apart from climate datasets, NDVI was assembled from the Advanced Very High Resolution Radiometer (AVHRR) sensors by the Global Inventory Monitoring and Modelling System (GIMMS) at semi-monthly (15d) time steps with a spatial resolution of $0.08^{\circ}$. NDVI 3g.v1 (third generation GIMMS NDVI from AVHRR sensors) was available from September 1981 to August 2015. The NDVI is an index that presents a range of values from 0 to 1 , and bare soil values are closer to 0 , while dense vegetation is close to 1 (Holben, 1986). NDVI 3g.v1 GIMMS provides information to differentiate valid values from possible errors due to snow, cloud, and interpolation. These errors were removed from the dataset and replaced with the nearest-neighbour value.

Additionally, the monthly land surface temperature (LST) was obtained from the Global Land Data Assimilation Sys- tem (GLDAS) by the Noah Land Surface Model L4 monthly version 2.0 (Beaudoing and Rodell, 2019). The dataset was available for the study period September 1981 to August 2015. The LST estimations from GLDAS were based on remotely sensed observations of AVHRR (Rodell et al., 2004) and include an algorithm that relies on an optimal interpolation routine (Ottlé and Vidal-Madjar, 1992) to assimilate the LST onto a $0.25^{\circ}$ by $0.25^{\circ}$ grid. This data record was selected due to its temporal resolution; however, it is important to mention that a higher spatial resolution could improve the accuracy of agricultural analyses and further reduce the uncertainties of the data noise originating from land heterogeneity.

Finally, the study was conducted for the agricultural land in the Bolivian Altiplano $\left(\sim 200000 \mathrm{~km}^{2}\right)$. The agricultural land was spatially identified based on the land use map developed by the Autonomous Authority of the Lake Titicaca (for the northern Altiplano) in 1995 at a scale of $1: 250000$ (UNEP, 1996) and the Ministry of Development Planning in 2002 using Landsat imagery and ground information at a scale 1:1000 000 (http://geo.gob.bo/portal/, last access: 15 May 2019, for the southern Altiplano).

\section{Methodology}

The analysis of drought impact on agriculture for the Bolivian Altiplano and its relationship with the ENSO is based on the following three steps. Firstly, an evaluation of satellite precipitation and gridded air temperature against gauged datasets was performed to investigate the accuracy of these estimates compared to empirical on-the-ground data. Secondly, the severity of drought was classified using vegetation and land surface temperature data, and using this information drought events were associated with the ENSO variability. Finally, a stepwise regression approach was used to study the variability of vegetation and its relationship with corresponding climate variables. The overall aim of our study is to investigate drought effects on agriculture through the analysis of land surface and climate variations and their relation to the ENSO anomalies.

\subsection{Evaluation of climate data}

The performance of the satellite-based data (compared to empirical ground data; see Fig. 2) in accurately estimating the amount of rainfall (for example rain detection capability purposes) was based on statistical measures for monthly pairwise time series, including categorical analyses, and follows methodologies suggested and applied in previous studies in this region, which were selected for comparison reasons (Blacutt et al., 2015; Satgé et al., 2016). The mean error (ME), bias, and mean absolute error (MAE) were calculated based on Wilks (2006). These measures evaluate the prediction accuracy of the satellite data compared to gauged 

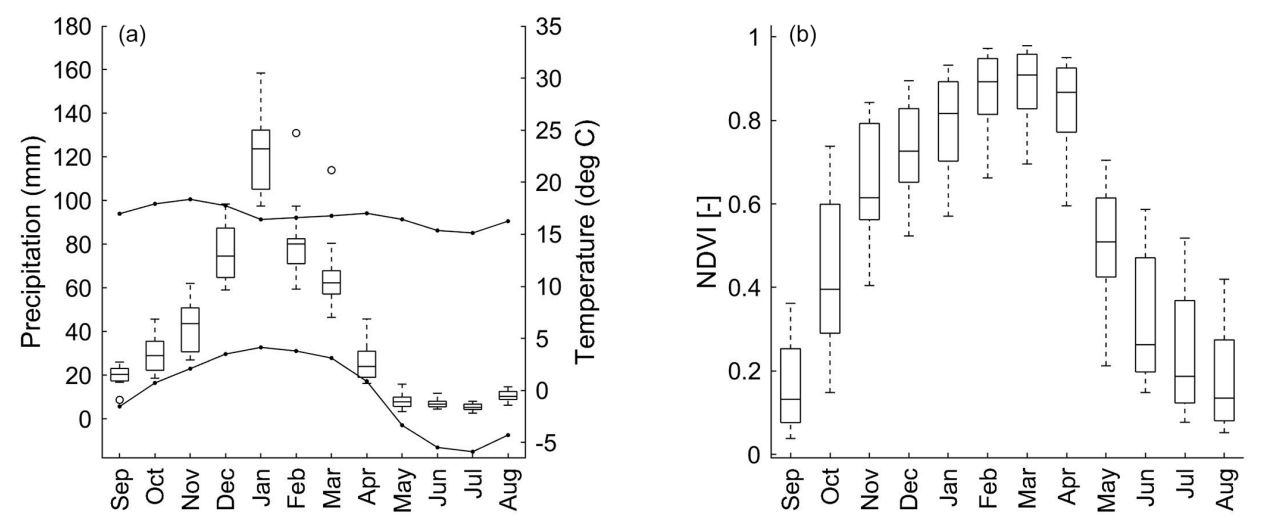

Figure 1. (a) Gauged mean monthly total precipitation and average maximum and minimum temperature from September 1981 to August 2015. (b) Mean monthly NDVI at the same spatial locations. Lower and upper box boundaries show the 25 th $\left(Q_{1}\right)$ and 75 th $\left(Q_{3}\right)$ percentiles, respectively; the line inside the box is the median; the lower and upper error lines indicate 1.5 times the interquartile range $\left(Q_{3}-Q_{1}\right)$ from the top or bottom of the box; white circles represent data falling outside 1.5 times the interquartile rage.

data. The ME and bias show the degree of over- or underestimation (Duan et al., 2015). In contrast, as with measuring the absolute deviation, MAE shows only non-negative values. The ME, bias, and MAE perfect match corresponds to zero between gauge observation and satellite-based estimate. Furthermore, and similar to Blacutt et al. (2015) and Satgé et al. (2016), the Spearman rank correlation was computed to estimate the goodness of fit to observations. To evaluate results, and in accordance with similar studies, correlation coefficients larger or equal to 0.7 were considered reliable (Condom et al., 2011; Satgé et al., 2016). The ME, bias, and MAE were calculated according to Eqs. (1), (2), and (3) in Table 1, respectively.

Two statistical indicators based on contingency tables were computed for the categorical statistics, namely probability of detection (POD) and false alarm ratio (FAR). The POD indicates what fraction of the observed events was correctly estimated, and FAR indicates the fraction of the predicted events that did not occur (Bartholmes et al., 2009; Ochoa et al., 2014; Satgé et al., 2016). The POD and FAR range from 0 to1, where 1 is a perfect score for POD, and 0 is a perfect score for FAR. These measures were used to evaluate the satellite precipitation estimations. Here, the rainfall amounts are considered as binary values, i.e. rain occurrence or absence. Based on this approach, three counting variables were taken into account: the number of events when the satellite rain estimation and the rain gauge report a rain event (hit or $\mathrm{H}$ ), when only the satellite reports a rain event but no rain on the ground is observed (false alarm or F), and when only the rain gauge reports a rain event but not the satellite and therefore is a miss (M). The POD and FAR were calculated according to Eqs. (4) and (5) in Table 1, respectively.

Besides the precipitation data, the gridded air temperature data were evaluated using ground data. The gridded air temperature was correlated with the mean gauged temperature at the same spatial location. The mean temperature of the gauged data was calculated using the arithmetic mean between the maximum and minimum temperature. The regression performance was evaluated using the monthly pairwise time series to define the Spearman rank correlation, relative ME, bias, and MAE. For air temperature, the MAE was defined using absolute values.

\subsection{Drought associated with ENSO}

Healthy vegetation usually shows enlarged near infrared and reduced visible bands and emits less absorbed thermal infrared radiation, resulting in lower surface temperature (Kogan and Guo, 2017). Therefore, vegetation indices and land surface temperature (LST) are widely used for water and energy balance approaches (see Moran et al., 1994; Corbari et al., 2010; Sánchez et al., 2012; Helman et al., 2015). Previous findings indicate a negative (positive) relationship between LST and NDVI caused by limited moisture (energytemperature) availability for vegetation growth (Karnieli et al., 2010). Drought spells typically present low NDVI and high LST due to vegetation deterioration and higher contribution of the soil signal (Kogan, 2000). Here, we study the relationship between LST and NDVI using the vegetation health index (VHI, Eq. 8) developed by Kogan (1995) that combines the vegetation condition index (VCI, Eq. 6) and temperature condition index (TCI, Eq. 7). VCI compares the current NDVI with the range of NDVI observations during the study period that allows us to seek the variability of the signal, showing an increased VCI when NDVI increases. (Kogan, 1995; Kogan, 2000; Kogan and Guo, 2017). In contrast, the TCI formulates a reverse ratio compared to the VCI, decreasing when LST increases, assuming that higher land surface temperatures suggest a decreasing soil moisture causing stress of the vegetation canopy.

The VCI, TCI, and VHI was defined for each month during the growing season (from September to April). We as- 
Table 1. Accuracy measures for the performance evaluation of climate estimated variables. Here, $N$ is the number of samples, $S_{i}$ is the climate estimation for month $i$, and $G_{i}$ is the gauged dataset for the same month. $\mathrm{H}$ is a hit, $\mathrm{F}$ is a false alarm, and $\mathrm{M}$ is a miss.

\begin{tabular}{lllll}
\hline Statistical indicator & Abbreviation & Units & \multicolumn{2}{c}{ Equation } \\
\hline Mean error & ME & $\mathrm{mm},{ }^{\circ} \mathrm{C}$ & $\sum\left(S_{i}-G_{i}\right) / N$ & $(1)$ \\
Bias & Bias & $\%$ & $\sum\left(S_{i}-G_{i}\right) / \sum G_{i} \times 100$ & $(2)$ \\
Mean absolute error & MAE & $\%$ & $\sum\left|\left(S_{i}-G_{i}\right) / G_{i}\right| / N \times 100$ & $(3)$ \\
Probability of detection & POD & - & $H /(H+M)$ & $(4)$ \\
False alarm ratio & FAR & - & $F /(H+F)$ & $(5)$ \\
\hline
\end{tabular}
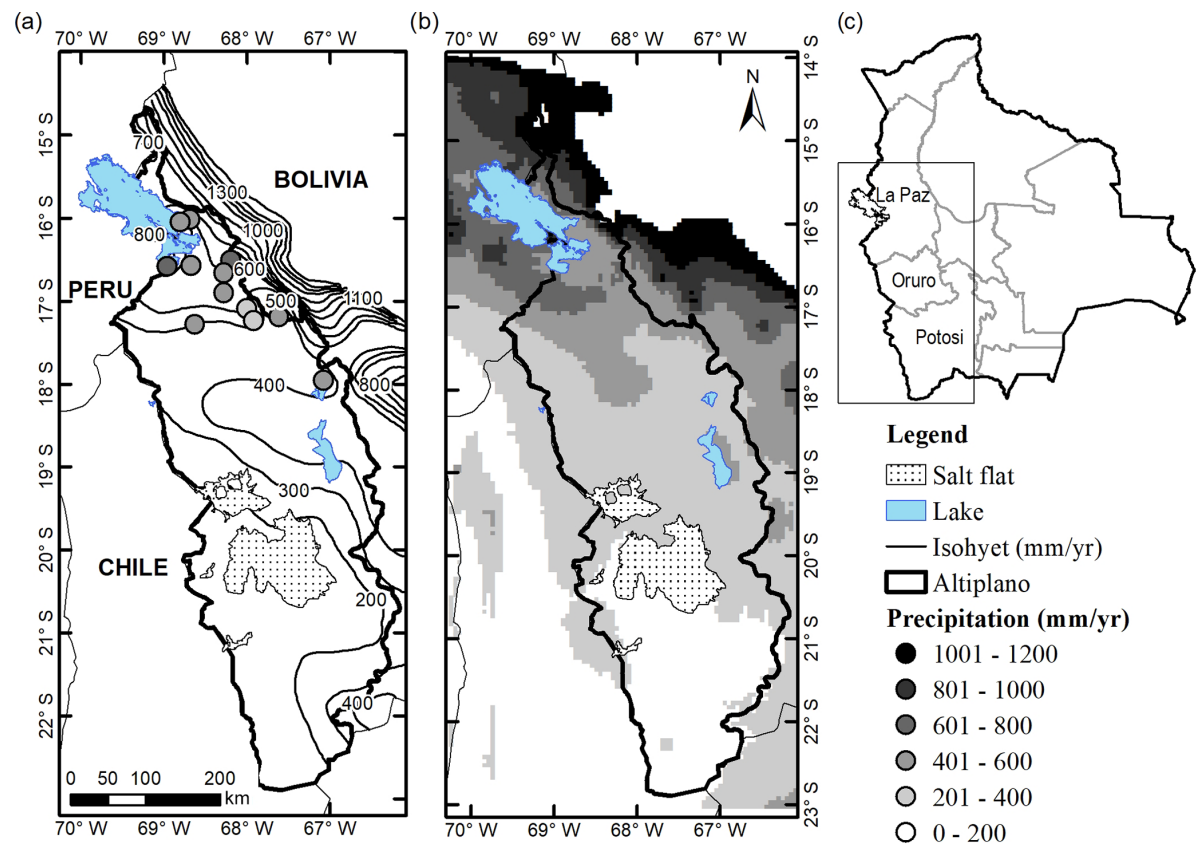

Figure 2. Mean of total annual precipitation from September 1981 to August 2015 for (a) gauged precipitation data (circles) and isohyets (solid line), (b) the CHIRPS satellite rainfall product, and (c) major political divisions of Bolivia.

sumed the occurrence of a drought event when the indices were lower than $40 \%$. The classification of drought was established based on the severity of the event in which five classes were defined: extreme $(\leq 10)$, severe, $(\leq 20)$, moderate $(\leq 30)$, mild $(\leq 40)$, and no $(>40)$ drought (Bhuiyan and Kogan, 2010).

The drought events were further classified based on the occurrence of El Niño and La Niña events (Table 3). The classification ENSO was obtained from Null (2018). El Niño and La Niña events were identified from five consecutive overlapping 3-month mean sea surface temperatures for the Niño 3.4 region (in the tropical Pacific Ocean). A moderate El Niño (La Niña) was defined as five consecutive overlapping 3 -month periods at or above the +1.0 to $+1.4{ }^{\circ} \mathrm{C}$ anomaly $\left(-1.0\right.$ to $-1.4^{\circ} \mathrm{C}$ ), a strong El Niño (La Niña) event for a threshold between the +1.5 and $+1.9^{\circ} \mathrm{C}$ anomaly $(-1.5$ to $-1.9^{\circ} \mathrm{C}$ anomaly), and a very strong El Niño event for a threshold equal to or greater than the $+2{ }^{\circ} \mathrm{C}$ anomaly (https: //ggweather.com/enso/oni.htm, last access: 15 May 2020).
For this study, a neutral or weak phase was defined as a threshold between the -0.9 and $+0.9^{\circ} \mathrm{C}$ anomaly.

\subsection{Regression of vegetation and climate variables}

A stepwise regression approach was used to quantify the dependency between vegetation and climate variables (satellitebased precipitation and gridded air temperature; Eq. 10) to be used for the hotspot selection process. In more detail, the results presented here are a combination of forward and backward selection techniques to increase the robustness of the results (in terms of explanatory power, i.e. variability explained, as well as variable selection, i.e. same variable selected across a range of possible models). The independent variable considered was NDVI, and the dependent variables were selected to include precipitation and air temperature (for the same spatial location across the study region). We assumed that NDVI represents the crop phenological stages of the growing season that is from September to April (Fig. 1). Precipitation was selected as a predictor due to its relevance 
Table 2. Drought classification indices.

\begin{tabular}{llll}
\hline Drought index & Abbreviation & \multicolumn{1}{c}{ Equation } \\
\hline Vegetation condition index & VCI & $\left(\mathrm{NDVI}_{i}-\mathrm{NDVI}_{\min }\right) /\left(\mathrm{NDVI}_{\max }-\mathrm{NDVI}_{\min }\right)$ & $(6)$ \\
Temperature condition index & TCI & $\left(\mathrm{LST}_{\max }-\mathrm{LST}_{i}\right) /\left(\mathrm{LST}_{\max }-\mathrm{LST}_{\min }\right)$ & (7) \\
Vegetation health index & VHI & $0.5 \mathrm{VCI}+0.5 \mathrm{TCI}$ & (8) \\
\hline
\end{tabular}

Here, $\mathrm{NDVI}_{i}\left(\mathrm{LST}_{i}\right)$ is the monthly NDVI (LST) and $\mathrm{NDVI}_{\max }$ and $\mathrm{NDVI}_{\min }\left(\mathrm{LST}_{\max }\right.$ and $\left.\mathrm{LST}_{\min }\right)$ are its multi-year absolute maximum and minimum (1981-2015), respectively. We took a mean of VCI and TCI assuming that they equally contribute to the VHI.

Table 3. El Niño and La Niña phases (from Null, 2018).

\begin{tabular}{lll|ll}
\hline & \multicolumn{2}{c|}{ El Niño } & \multicolumn{2}{c}{ La Niña } \\
\hline Moderate & Strong & Very strong & Moderate & Strong \\
\hline $1986-1987$ & $1987-1988$ & $1982-1983$ & $1995-1996$ & $1988-1989$ \\
$1994-1995$ & $1991-1992$ & $1997-1998$ & $2011-2012$ & $1998-1999$ \\
$2002-2003$ & & $2015-2016$ & & $1999-2000$ \\
$2009-2010$ & & & & $2007-2008$ \\
& & & & $2010-2011$ \\
\hline
\end{tabular}

for water availability for vegetation growth. Precipitation is the main source of water in the Altiplano because only $9 \%$ of the Bolivian cropped surface area is irrigated (INE, 2015). Air temperature is a relevant variable due to photosynthetic and respiration processes (Karnieli et al., 2010). Firstly, the NDVI was related to CHIRPS rainfall datasets. Secondly, air temperature was included in the analysis. Here, only the NDVI grids for agricultural land were selected. Since, agricultural production data are scarce in the region, we suggest that crop yield data can be improved using the NDVI. Besides improving the crop yield resolution, the NDVI also allows us to analyse the variability of vegetation at a monthly timescale. This makes it possible to analyse the phenology of the studied crops through to the growth phases. NDVI estimates the vegetation vigour (Ji and Peters, 2003) and crop phenology (Beck et al., 2006). The final regression model for each spatial unit was defined as

$\mathrm{NDVI}=\beta_{0}+\beta_{1}$ precipitation $+\beta_{2}$ air temperature.

For the forward selection, the variables were entered into the model one at a time in an order determined by the strength of their correlation with the criterion variable (only including variables if they present a confidence level of $95 \%$ ). The effect of adding each variable was assessed during its entering stage, and variables that did not significantly add to the fit of the model were excluded (Kutner et al., 2004). For backward selection, all predictor variables were entered into the model first. The weakest predictor variable was then removed and the regression fit re-calculated. If this significantly weakened the model, then the predictor variable was re-entered; otherwise it was deleted. This procedure was repeated until only useful predictor variables (in a statistical sense, e.g. significant as well as model fit) remained in the model (Rencher,
1995). The results were compared with results from the literature regarding phenology and weather-related characteristics of crops.

It should be noted that the precipitation in the Altiplano shows a marked rainy season from November to March. The peak of precipitation is in December and January (Fig. 1a). Additionally, NDVI displays a peak in March and April (Fig. 1b). The lag between the precipitation and NDVI is reasonable since vegetation requires time to grow (e.g. Shinoda, 1995; Cui and Shi, 2010; Chuai et al., 2013). Considering this lag time, the 3-month time series of NDVI was regressed with the 3-month time series of the climate variables (satellite-based data product of precipitation and gridded data of air temperature) during the growing period for the agricultural land. First, the NDVI and the climate variables were related considering the overlapping 3-month time series, and afterwards a relation was developed considering a lag from 1 to 4 months between NDVI and climate variables, resulting in 22 regressions per NDVI grid. The regressions were developed for each NDVI grid separately, associated with the nearest precipitation and air temperature dataset. Prior to the stepwise regression analysis, the 3-month time series of NDVI, satellite precipitation, and gridded air temperature data were standardized.

\section{Results}

Validation of the satellite rain data using empirical precipitation data from the weather stations was done for the 12 locations where gauge precipitation data were available (see Fig. 2 and Table A1). The qualitative methods discussed in Sect. 3.1 for the CHIRPS rainfall estimates show differences between summer (from December to March) and winter sea- 
son (from June to August). CHIRPS data show better accuracy during summer. The precipitation during the austral summer is highly relevant because it concentrates the $70 \%$ of the annual rainfall (Garreaud et al., 2003), and it occurs during the growing season. During May, CHIRPS data show lower accuracy compared to the other months. The precipitation from May to August is almost null in the study area (Fig. 1), and it will be further described as the dry season. This season presents stable atmospheric conditions with few precipitation events (Garreaud et al., 2003).

Interestingly, the Spearman rank correlation between monthly gauged precipitation and satellite rain product datasets was significant $(p$ value $<0.05)$ for all locations. The correlation coefficients $(r)$ vary from 0.5 to 0.8 (mean =0.7). The ME and bias disclose an underestimation of precipitation estimation during October, November, and April and an overestimation during the summer season (mean $=5 \mathrm{~mm}$ and $7 \%$, respectively) with a peak in February. For the MAE coefficient, CHIRPS estimations are more accurate during the rainy season (mean $=31 \%$ ). In contrast, CHIRPS data indicate poor accuracy during the dry season (mean MAE $=92 \%$ ). From June to August, CHIRPS data present an underestimation of the gauged precipitation (mean bias $=-39 \%$ ). Summarizing these observations, we conclude that the CHIRPS rainfall dataset is more accurate during the rainy season, and it represents an adequate alternative in case of lack of gauged data or in case of poor data quality. However, it should be noted that such data still must be used with caution considering the uncertainties due to the under- or overestimation of precipitation along the heterogeneous topography of the Altiplano (see Paredes-Trejo et al., 2016; Paredes-Trejo et al., 2017; Rivera et al., 2018).

Moving from rainfall to temperature, the inter-annual temperature at the eight locations varied considerably between summer (from December to March) and winter (from June to August), including a larger variance for the minimum temperature (Fig. 1a). The mean monthly air temperature from gridded data was compared with mean temperature of gauged data. The gridded air temperature underestimated the mean gauged temperature, and this error could be due to the heterogeneous topography and high elevation. The Spearman correlation at the eight stations displayed coefficients from 0.1 to 0.7. From November to April, the gridded air temperature data show significant correlations $(p$ value $<0.05)$. Large correlations are shown during summer season $($ mean $=0.7$ ), while the other months show rather weak correlations. ME and bias show a slight underestimation from October to April (mean $=-0.5^{\circ} \mathrm{C}$ and $-4 \%$ respectively) and an overestimation from May to August (mean $=0.3 \%$ and $12 \%$ respectively). Finally, MAE is about $1.2{ }^{\circ} \mathrm{C}$ from September to April, and higher values develop during winter season (mean $\left.=1.6^{\circ} \mathrm{C}\right)$. In conclusion, the gridded air temperature data product performs better from November to April. Similar to the precipitation data, the application of gridded air temperature data must take into account the potential errors due to the estimation uncertainties, mainly during winter season.

As discussed above, the VCI, TCI, and VHI were calculated during the growing season. The sowing period depends on the initial soil moisture content; therefore the beginning of the growing season oscillates from September to November (Garcia et al., 2015). For this reason, the drought severity was classified considering the mean of VCI, TCI, and VHI for the agricultural land during November-April. Figure A1 shows mean monthly VCI from November 1981 to April 2015. The major drought events (severe or extreme) are visible in 19821983, 1983-1984, and 2009-2010, followed by moderate drought events during 1987-1988 and 1993-1994, as well as several mild events. Figure A2 shows the mean monthly TCI, where the major drought events (severe or extreme) occurred in 1982-1983, 1987-1988, 1997-1998, 2004-2005, and 2009-2010, followed by moderate drought events during 1981-1982, 1983-1984, 1994-1995, 2006-2007, and 20082009, and several mild events as well. Finally, Fig. A3 shows the VHI results, in which the major drought events occurred during 1982-1983, 2004-2005, and 2009-2010.

In a next step we related drought indices with the ENSO phases (Table 4). Extreme and severe droughts were generally found during the El Niño phase. The extreme drought of 1982-1983 coincided with a very strong El Niño phase. For this event, the largest economic losses caused by droughts during the study period are reported (Table 5), followed by the very strong El Niño phase of 1997-1998, which reported the second largest economic losses. Besides these two main drought events, the strong El Niño during 1987-1988 coincided with an extreme/moderate drought (TCI $\leq 10 \%$, $\mathrm{VCI} \leq 30 \%$ ) classification. During this period, large economic losses were reported as well (Table 5). In contrast, the strong El Niño during 1991-1992 showed low severity (mild drought $\mathrm{VCI} \leq 40 \%$ ), and no economic losses were reported. This indicates that despite the fact that the El Niño phenomenon is generally associated with drought in the Altiplano, there are several other mechanisms that drive a drought occurrence and determine its severity. For instance, dry (wet) and warm (cool) conditions during El Niño (La Niña) phases are generally shown in the Altiplano (Garreaud et al., 2003). However, an anomalous location and intensity of zonal wind anomalies could cause disturbances of the warming and cooling air patterns causing rainfall anomalies in the region (Garreaud and Aceituno, 2001). This is the case of the dry La Niña during 1988-1989 that showed a mild drought classification (TCI $\leq 40 \%$ ).

One severe (1983-1984) and one extreme (2004-2005) event occurred during a neutral/weak ENSO. The severe drought (VCI $\leq 20 \%$ ) occurred during a neutral phase of 1983-1984. This coincides with the findings of VicenteSerrano et al. (2015) that analysed the standardized precipitation/evaporation index in Bolivia, which is an alternative technique to characterize a meteorological drought. The extreme drought (TCI $\leq 10 \%$ ) of 2004-2005 occurred 

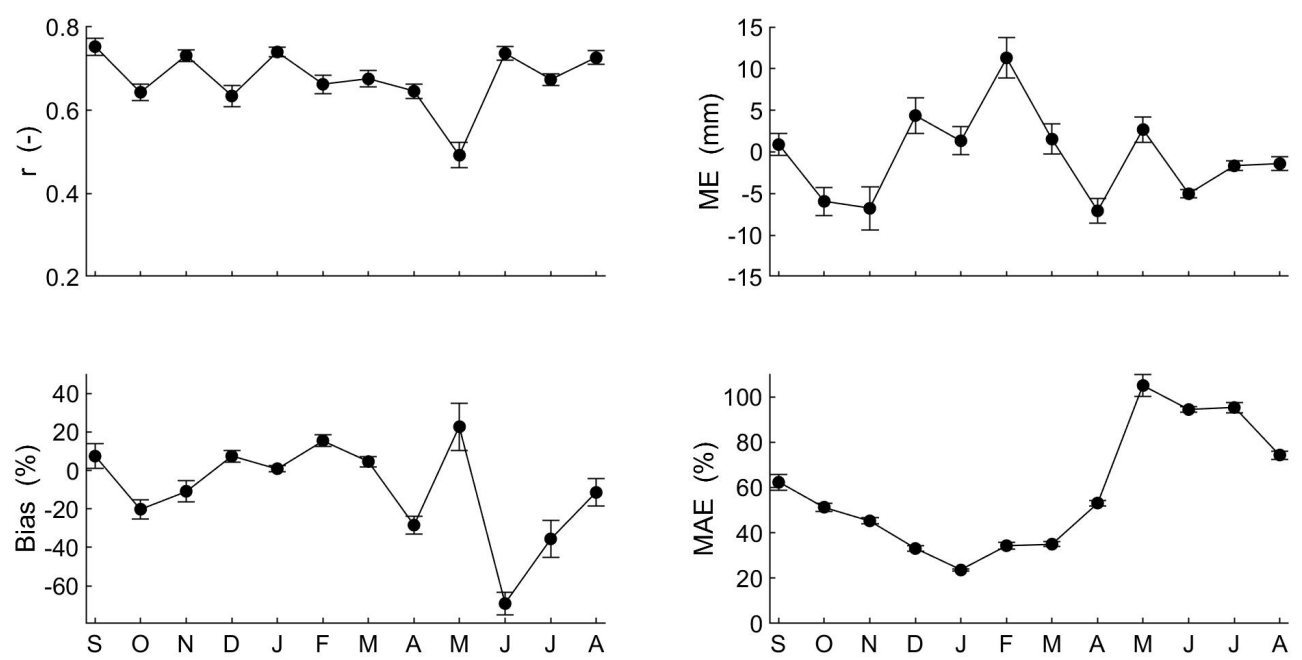

Figure 3. Monthly accuracy measures of CHIRPS rainfall data product. Mean monthly values are represented by black circles, and bars represent the standard error of the mean.
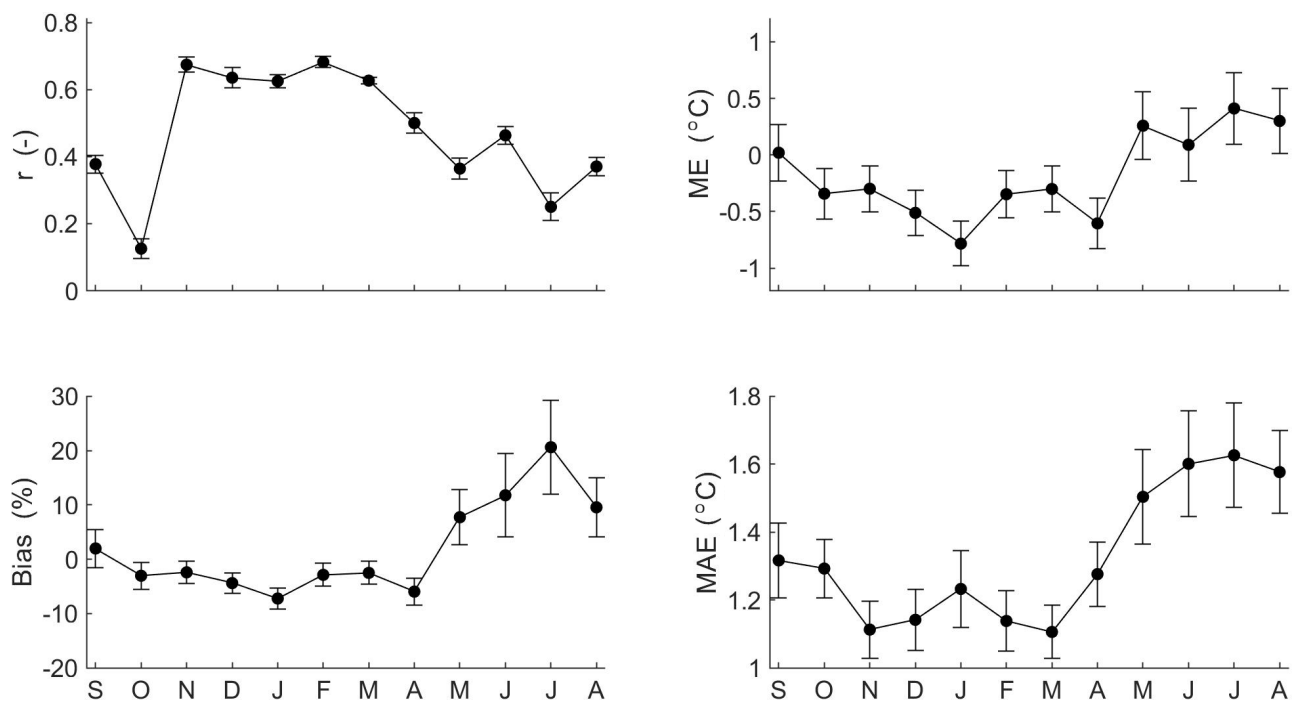

Figure 4. Same as Fig. 3 but for accuracy measures of the gridded air temperature data product.

in November and December. From January to April of 20042005 the VCI and VHI were above $40 \%$, and there were no claims of drought losses in the Altiplano for this particular year (Table 5). Besides these two events, moderate and mild droughts also occurred during non-El Niño phases.

Table 5 shows that five drought events were reported during a neutral ENSO phase. In 2012-2013, the largest impact occurred, affecting about 80000 people in the Altiplano (Desinventar Sendai, 2020). Despite the fact that the mean of the drought indices indicates no drought during this period (VCI, TCI, and VHI $>40 \%$ ), some spatial locations in the study region indicated the occurrence of a drought event in November and December $(21 \%$ and $29 \%$ of the total studied grids showed mild and moderate droughts for the TCI and VCI respectively).
Regarding the relationship between vegetation and climate variables, we note that the precipitation season occurs mainly during the austral summer months (from December to March), and the vegetation development shows a lag with a maximum development around March and April (Fig. 1). The NDVI (Fig. 1b) shows a similar growing pattern to the crop phenology in the region, which starts in September and ends in April. Maximum and minimum temperature varies during the year. Higher temperature during the austral summer leads to higher evapotranspiration and a decrease in water retained in the root zone. With this presumption, stepwise linear regression models were tested using 3-month time series of NDVI as the dependent variable and 3-month time series of satellite-based data product of precipitation and gridded air temperature as independent variables (Eq. 10). The 
Table 4. Drought index classification during ENSO phases.

\begin{tabular}{|c|c|c|c|c|}
\hline ENSO & Drought & VCI & TCI & VHI \\
\hline \multirow[t]{4}{*}{ El Niño } & Extreme & & $\begin{array}{l}1982-1983,1987-1988,1997- \\
1998\end{array}$ & \\
\hline & Severe & 1982-1983, 2009-2010 & 2009-2010 & 1982-1983, 2009-2010 \\
\hline & Moderate & $1987-1988$ & 1994-1995 & \\
\hline & Mild & 1986-1987, 1991-1992 & 1986-1987 & 1994-1995, 1997-1998 \\
\hline La Niña & Mild & $\begin{array}{l}\text { 1995-1996, 2007-2008, 2010- } \\
2011\end{array}$ & 1988-1989 & \\
\hline \multirow[t]{4}{*}{ Neutral/weak } & Extreme & & 2004-2005 & \\
\hline & Severe & 1983-1984 & & \\
\hline & Moderate & 1993-1994 & $\begin{array}{l}\text { 1981-1982, 1983-1984, 2006- } \\
2007,2008-2009\end{array}$ & 2004-2005 \\
\hline & Mild & $\begin{array}{l}\text { 1981-1982, 1996-1997, 2003- } \\
2004,2008-2009\end{array}$ & $\begin{array}{l}\text { 1984-1985 1990-1991, 1993- } \\
1994,2014-2015\end{array}$ & $\begin{array}{l}1981-1982, \quad 1983-1984, \quad 1990- \\
1991, \quad 1993-1994, \quad 2005-2006, \\
2008-2009\end{array}$ \\
\hline
\end{tabular}

Table 5. Drought impact in Bolivia (from EM-DAT, 2020, BID, 2016, and CAF, 2000).

\begin{tabular}{llll}
\hline Year & ENSO phase & Affected people & $\begin{array}{l}\text { Total damage } \\
\text { (thousands of USD) }\end{array}$ \\
\hline $1982-1983$ & El Niño & 3083049 & 917200 \\
$1987-1988$ & El Niño & & 48400 \\
$1989-1990$ & Neutral & 283160 & \\
$1997-1998$ & El Niño & & 279310 \\
$1993-1994$ & Neutral & 50000 & \\
$1999-2000$ & La Niña & 20000 & \\
$2003-2004$ & Neutral & 55000 & 100000 \\
$2007-2008$ & La Niña & 27500 & \\
$2009-2010$ & El Niño & 62500 & \\
$2012-2013$ & Neutral & 340355 & \\
$2013-2014$ & Neutral & 51180 & \\
\hline
\end{tabular}

stepwise regression was defined considering the overlapped 3-month time series and the 3-month time series with a lag from 1 to 4 months at the same spatial location over the agricultural land.

The results of the stepwise regression show a larger coefficient of determination $\left(R^{2}\right)$ in the northern and central Bolivian Altiplano, starting from the southern Lake Titicaca and moving southwards to Lake Poopó, and close to the rivers' paths. Lower $R^{2}$ values are shown along the southwestern Bolivian Altiplano that could be explained through the large variance of the NDVI, which may depend to on other factors besides precipitation and temperature, including crop management. Figure 5 shows the $R^{2}$ of the best fit regression in the Bolivian Altiplano for the 3-month period of NDVI and the climate variables (precipitation and temperature) during the beginning and end of the growing season. It can be seen that the NDVI depends largely on the studied climate variables. This may be due to the crop's sensitivity for water stress during specific stages of the growing season. For instance the most sensitive stages of the quinoa crop are the emergence, flowering, and grain development (see Geerts et al., 2008; Geerts et al., 2009), as well as the near absence of irrigation practices in most of these regions.

In more detail, the stepwise regression results for the overlapping 3-month time series of NDVI and climate variables for SON (September, October, and November) show statistically significant coefficients for precipitation and air temperature at $45 \%$ and $98 \%$ of the agricultural area in the Bolivian Altiplano with a median of 0.2 and 0.7 , respectively (Fig. 5a). This indicates that the NDVI increases with more rain and higher air temperature. Interestingly, the significant regression coefficients of NDVI for OND (October, November, and December) associated with precipitation and air temperature for SON cover $64 \%$ and $91 \%$ of the agricultural area and have a positive median of 0.3 and 0.4 , respectively (Fig. 5b). A time lag of 1 month shows larger spatial coverage of the response of vegetation to precipitation anomalies. Here, the largest coefficient of determination are shown in areas surrounding the Lake Titicaca. Moreover, the response of the NDVI for MAM (March, April, and May) to the studied climate anomalies for FMA (February, March, and April) covers $95 \%$ and $96 \%$ of the agricultural land for precipitation and air temperature, respectively (Fig. 5c). This mostly shows coefficients of determination ranging from 0.4 to 0.8 , and positive regression coefficients for precipitation and air temperature have a median of 0.5 and 0.4 , respectively. The hours of sun required for crop development could be an explanation for the time lag between vegetation and the climate 


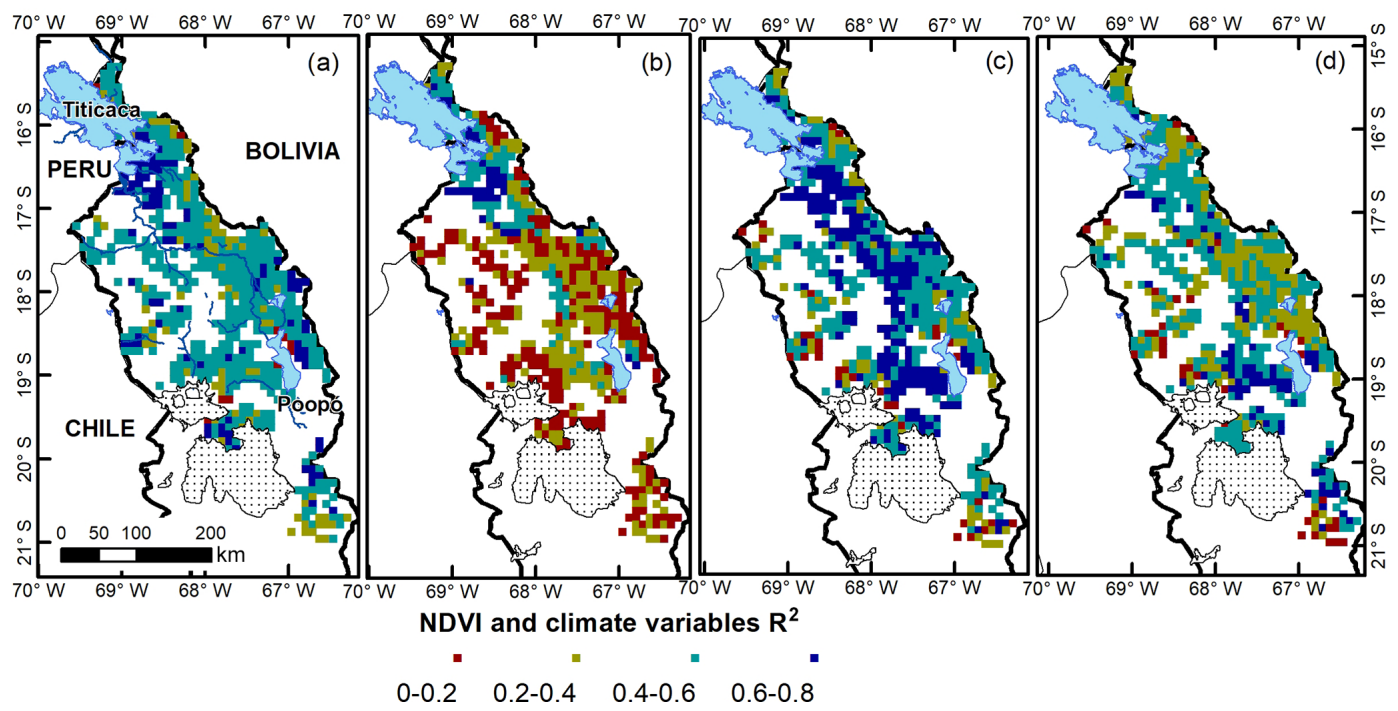

Figure 5. Coefficient of determination $\left(R^{2}\right)$ of NDVI for the 3-month time series for (a) SON, (b) OND, (c) MAM, and (d) MAM and the climate variables (satellite precipitation and gridded air temperature products) for SON, SON, FMA, and MAM respectively. The significant regression coefficients for precipitation (air temperature) cover (a) $45 \%(98 \%)$, (b) $64 \%$ (91\%), (c) $95 \%$ (96\%), and (d) $23 \%$ (98\%) of the total studied grids that represent the agricultural land.

variables. In addition, the lag differences between vegetation and precipitation can be partly explained by the topography, land cover, groundwater, and soil properties (Quiroz et al., 2011; Yarleque et al., 2016). Finally, the regression for NDVI and climate variables for the overlapped 3-month time series of MAM shows significant coefficients at $23 \%$ and $98 \%$ of the agricultural land, with a median of 0.4 and 0.6 for precipitation and air temperature, respectively (Fig. 5d). Hence, the vegetation response to precipitation is limited for the last overlapped 3-month time series of the growing season. However, it should be noted that air temperature remains an important variable.

To summarize, while acknowledging some important limitations, we found that the CHIRPS dataset is adequate to be used for drought risk assessment in case of severe data scarcity for the Bolivian Altiplano. Furthermore, we found that the vegetation variance can be significantly explained by precipitation and air temperature. More specifically, we point out the relevance of precipitation as the main water source for vegetation development and air temperature as a driver of photosynthetic processes. Precipitation is particularly important at the early and late phenological stages, in which crops are more sensitive to water shortage. This is the case for the main crops in the region, i.e. quinoa and potato. For the quinoa crop, the most sensitive phases to water stress are the emergence, flowering, and grain development (see Geerts et al., 2008; Geerts et al., 2009). The most sensitive phases of the potato crop to water stress is the tuber initiation and bulking (van Loon, 1981; Alva et al., 2012). On the other hand, air temperature is relevant for vegetation productivity, and overall we found a positive relation between vegetation and air temperature. However, in prolonged dry periods, high air temperature could increase the evapotranspiration rates and consequently decrease the soil moisture (Huang et al., 2019). This scenario could impact negatively the vegetation, as this is the case of the drought events of 1982-1983 and 19971998, where large production losses were reported (Santos, 2006).

\section{Discussion and conclusion}

We employed satellite-based and gridded dataset products and tested the dataset's empirical accuracy as well as performance to similar (but with coarser resolution) datasets available for the Bolivian Altiplano region. Spatio-temporal patterns of satellite precipitation and gridded air temperature anomalies were explored based on monthly time series during the period September 1981 to August 2015. Drought severity was evaluated based on a drought classification scheme using NDVI and LST; this classification was related with the ENSO anomalies. Finally, association between the spatial distribution of NDVI with precipitation and air temperature was examined. Using these datasets, it was shown that drought severity (measured through various drought indices) increases substantially during El Niño years, and as a consequence the socio-economic drought risk of farmers will likely increase during such periods. ENSO forecasts as well as drought severity (through drought indices) can help to determine possible hotspots of crop deficits during the growing season. The empirical relationships of land surface and climate data on the local scale of our approach can support a proactive approach to disaster risk management against 
droughts, through an evaluation of the evolution of climate anomalies (in this case the ENSO) and their potential adverse effects in the region. As it was shown here, the ENSO-warmphase-related characteristics are especially important in the context of extreme drought events and could therefore be incorporated within early warning systems as standard practice. Despite these challenges for the development of drought early warning systems (see FAO, 2016, 2017), applications have been successful in the past (e.g. Global Information and Early Warning System (GIEWS) of FAO and Famine Early Warning System (FEWS) of USAID). Monitoring and predicting ENSO can therefore significantly contribute to reduce the risk of disasters. This study is a first attempt to provide an assessment of drought impact on agriculture in relation to the ENSO phenomenon for the Bolivian Altiplano. We focused on where vegetation is more affected by droughts over agricultural land and how this can be clarified using satellite imagery. It is important to note that the variance of drought indices (as well as NDVI) to a large extent is explained by precipitation and air temperature anomalies in the studied region. The agriculture in this semi-arid region is ecologically fragile, and the main water source is precipitation, and thus crop production is considerably affected by precipitation anomalies. However, while an overall response of vegetation variance to precipitation and air temperature is evident, it is important to consider other variables, such as evapotranspiration and soil moisture to improve risk-based models. Another important issue is the time lag of the response of vegetation to precipitation and air temperature anomalies, which shows a hysteresis of 1-2 months. These findings provide information for future drought risk management and early warning system applications. In addition, with such information agricultural models can be set up along with risk management plans with improved accuracy. 


\section{Appendix A}

Table A1. Spatial location of the studied weather stations where gauged precipitation data are available; the stations that also present temperature maximum and minimum data are indicated by $T$ on the temperature column.

\begin{tabular}{|c|c|c|c|c|c|}
\hline No. & Station name & Latitude & Longitude & Altitude & Temperature \\
\hline 1 & Ayo Ayo & -17.1 & -68.0 & 3888 & \\
\hline 2 & Calacoto & -17.3 & -68.6 & 3830 & $T$ \\
\hline 3 & Collana & -16.9 & -68.3 & 3911 & $T$ \\
\hline 4 & El Alto Aeropuerto & -16.5 & -68.2 & 4034 & $T$ \\
\hline 5 & El Belen & -16.0 & -68.7 & 3833 & $T$ \\
\hline 6 & Oruro Aeropuerto & -18.0 & -67.1 & 3701 & $T$ \\
\hline 7 & Patacamaya & -17.2 & -67.9 & 3793 & \\
\hline 8 & Salla & -17.2 & -67.6 & 3500 & \\
\hline 9 & San Juan Huancollo & -16.6 & -68.9 & 3829 & \\
\hline 10 & Santiago de Huata & -16.1 & -68.8 & 3845 & $T$ \\
\hline 11 & Tiahuanacu & -16.6 & -68.7 & 3863 & $T$ \\
\hline 12 & Viacha & -16.7 & -68.3 & 3850 & $T$ \\
\hline
\end{tabular}

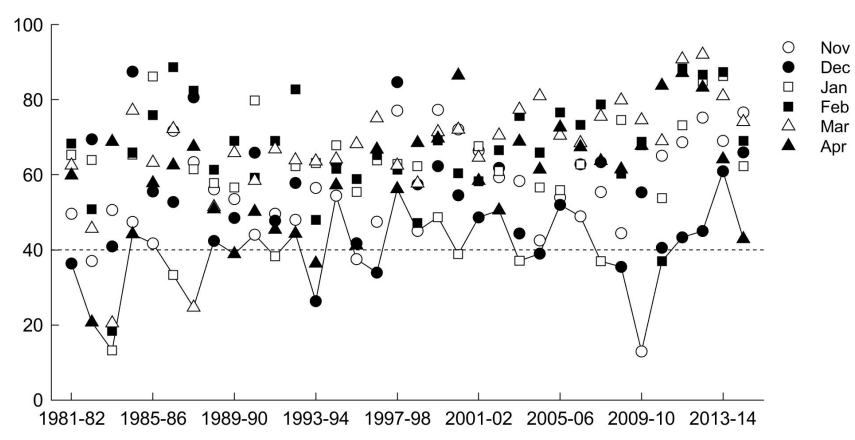

Figure A1. Monthly mean VCI (\%) from November 1981 to April 2015. Solid line indicates the minimum monthly value along the study period. Values below $40 \%$ (dashed line) represent a drought event.

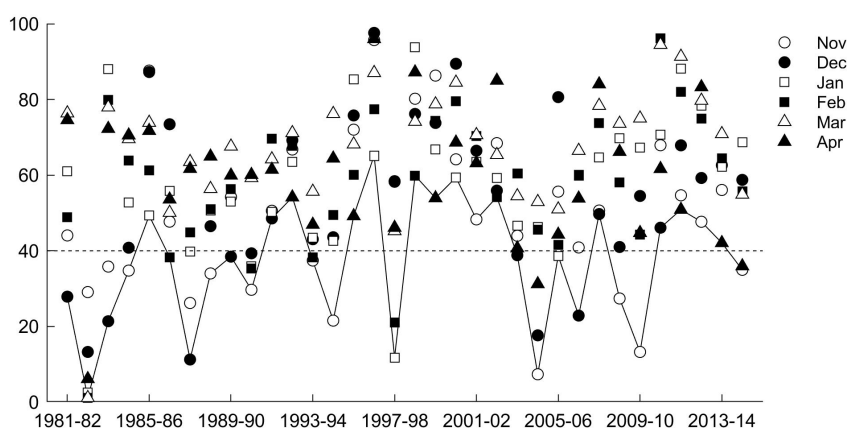

Figure A2. Same as Fig. A1 but for the TCI.

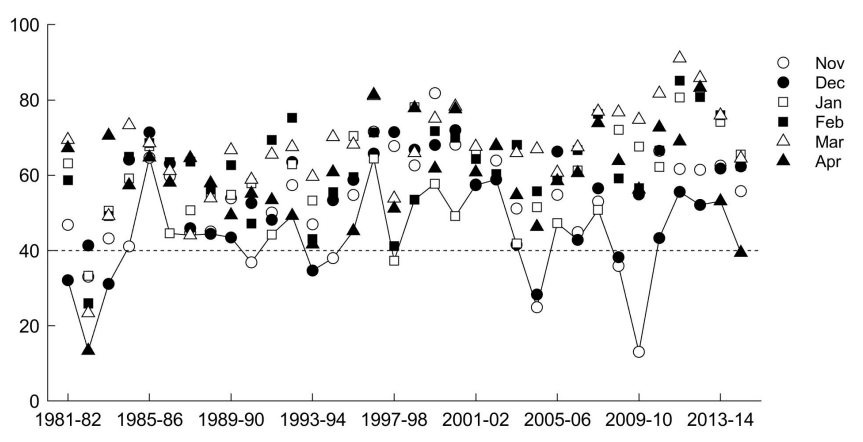

Figure A3. Same as Fig. A1 but for the VHI. 
Code availability. For analysis we have used the MATLAB programming language. A script file is available in the Supplement.

Data availability. The data used in the study are open and downloadable at the websites: http://senamhi.gob.bo/index.php/sismet (SENAMHI 2019), https://data.chc.ucsb.edu/products/CHIRPS-2. 0/global_monthly/netcdf/ (Funk, 2015), https://psl.noaa.gov/data/ gridded/data.UDel_AirT_Precip.html (Willmott and Matsuura, 2001), https://doi.org/10.5067/9SQ1B3ZXP2C5 (Beaudoing and Rodell, 2019), https://climatedataguide.ucar.edu/climate-data/ndvinormalized-difference-vegetation-index-3rd-generation-nasagfscgimms (Pinzon and Tucker, 2018).

Supplement. The supplement related to this article is available online at: https://doi.org/10.5194/nhess-21-995-2021-supplement.

Author contributions. CCR conceived the study, collected the data, performed the analysis, interpreted the results, and wrote the article. SHS, GP, BC, and RB contributed to the writing and the interpretation of the results.

Competing interests. The authors declare that they have no conflict of interest.

Acknowledgements. The authors want to thank the reviewers for their thoughtful comments and efforts towards improving our paper. Special thanks go to the International Institute for Applied System Analysis (IIASA), in particular the Young Scientist Summer Program (YSSP) 2017, where this study was initiated. The authors thank the Swedish International Development Cooperation Agency (SIDA) and the FORMAS Swedish Research Council for Sustainable Development. The authors would like to express their gratitude to the Servicio Nacional de Meteorología e Hidrología (SENAMHI) for providing the meteorological data. The authors would also like to thank Ramiro Pillco Zolá and Ángel Aliaga Rivera for the coordination of the research project with the Universidad Mayor de San Andrés of Bolivia.

Review statement. This paper was edited by Gregor C. Leckebusch and reviewed by Christian Yarleque and two anonymous referees.

\section{References}

Aceituno, P.: On the Functioning of the Southern Oscillation in the South American Sector. Part I: Surface Climate, Mon. Weather Rev., 116, 505-524, https://doi.org/10.1175/15200493(1988)116<0505:OTFOTS>2.0.CO;2, 1988.

Alva, A. K., Moore, A. D., and Collins, H. P.: Impact of Deficit Irrigation on Tuber Yield and Quality of Potato Cultivars, J. Crop Improv., 26, 211-227, https://doi.org/10.1080/15427528.2011.626891, 2012.
Anderson, W., Seager, R., Baethgen, W., and Cane, M.: Life cycles of agriculturally relevant ENSO teleconnections in North and South America, Int. J. Climatol., 37, 3297-3318, https://doi.org/10.1002/joc.4916, 2017.

Bartholmes, J. C., Thielen, J., Ramos, M. H., and Gentilini, S.: The european flood alert system EFAS - Part 2: Statistical skill assessment of probabilistic and deterministic operational forecasts, Hydrol. Earth Syst. Sci., 13, 141-153, https://doi.org/10.5194/hess-13-141-2009, 2009.

Beaudoing, $H$. and Rodell, M.: NASA/GSFC/HSL: GLDAS Noah Land Surface Model L4 monthly $0.25 \times 0.25$ degree V2.0, Greenbelt, Maryland, USA, Goddard Earth Sciences Data and Information Services Center (GES DISC), https://doi.org/10.5067/9SQ1B3ZXP2C5, 2019.

Beck, P. S. A., Atzberger, C., Høgda, K. A., Johansen, B., and Skidmore, A. K.: Improved monitoring of vegetation dynamics at very high latitudes: A new method using MODIS NDVI, Remote Sens. Environ., 100, 321-334, https://doi.org/10.1016/j.rse.2005.10.021, 2006.

Bhuiyan, C. and Kogan, F. N.: Monsoon variation and vegetative drought patterns in the Luni Basin in the rainshadow zone, Int. J. Remote Sens., 31, 3223-3242, https://doi.org/10.1080/01431160903159332, 2010.

BID: Analisis ambiental y social, in: Programa de Saneamiento del Lago Titicaca, Banco Interamericano de Desarrollo (BID), La Paz, Bolivia, 2016.

Blacutt, L. A., Herdies, D. L., de Gonçalves, L. G. G., Vila, D. A., and Andrade, M.: Precipitation comparison for the CFSR, MERRA, TRMM3B42 and Combined Scheme datasets in Bolivia, Atmos. Res., 163, 117-131, https://doi.org/10.1016/j.atmosres.2015.02.002, 2015.

Buxton, N., Escobar, M., Purkey, D., and Lima, N.: Water scarcity, climate change and Bolivia: Planning for climate uncertainties, SEI discussion brief, Stockholm Environment Institute, Davis, USA, 4 pp., 2013.

CAF: Las lecciones de El Niño, Bolivia. Memorias del fenómeno El Niño 1997-1998, retos y propuestas para la región andina., Corporación Andina de Fomento (CAF), Caracas, Venezuela, 2000.

Chuai, X. W., Huang, X. J., Wang, W. J., and Bao, G.: NDVI, temperature and precipitation changes and their relationships with different vegetation types during 1998-2007 in Inner Mongolia, China, Int. J. Climatol., 33, 1696-1706, https://doi.org/10.1002/joc.3543, 2013.

Condom, T., Rau, P., and Espinoza, J. C.: Correction of TRMM 3B43 monthly precipitation data over the mountainous areas of Peru during the period 1998-2007, Hydrol. Process., 25, 1924 1933, https://doi.org/10.1002/hyp.7949, 2011.

Corbari, C., Sobrino, J. A., Mancini, M., and Hidalgo, V.: Land surface temperature representativeness in a heterogeneous area through a distributed energy-water balance model and remote sensing data, Hydrol. Earth Syst. Sci., 14, 2141-2151, https://doi.org/10.5194/hess-14-2141-2010, 2010.

Cui, L. and Shi, J.: Temporal and spatial response of vegetation NDVI to temperature and precipitation in eastern China, J. Geogr. Sci., 20, 163-176, https://doi.org/10.1007/s11442-0100163-4, 2010.

Desinventar Sendai: Disaster loss data for sustainable development goals and Sendai framework monitoring system. United nations 
office for disaster risk reduction (UNDRR), available at: https: //www.desinventar.net/, last access: 1 June 2020.

Duan, Y., Wilson, A. M., and Barros, A. P.: Scoping a field experiment: error diagnostics of TRMM precipitation radar estimates in complex terrain as a basis for IPHEx2014, Hydrol. Earth Syst. Sci., 19, 1501-1520, https://doi.org/10.5194/hess-19-1501-2015, 2015.

EM-DAT: The emergency events database. Center for research on the epidemiology of disasters (CRED), available at: https://www. emdat.be/, last access: 15 July 2020.

FAO: 2015-2016 El Nino early action and response for agriculture, Food security and nutrition, and Food and Agricultural Organization of the United Nations (FAO), Rome, Italy, 43 pp., ISBN 97892-5-109383-2, 2016.

FAO: Global early warning - Early action report on food security and agriculture July-September 2017, Early Warning - Early Action (EWEA), Agricultural Development Economics Division (ESA), and Food and Agricultural Organization of the United Nations (FAO), Rome, Italy, ISBN 978-92-5-109806-6, 27, 2017.

Funk, C.: Rainfall Estimates from Rain Gauge and Satellite Observations (CHIRPS), United States Geological Survey (USGS) and Climate Hazard Center of the University of California, Santa Barbara, available at: https://data.chc.ucsb.edu/products/ CHIRPS-2.0/global_monthly/netcdf/ (last access: 22 February 2021), 2015.

Funk, C., Peterson, P., Landsfeld, M., Pedreros, D., Verdin, J., Shukla, S., Husak, G., Rowland, J., Harrison, L., Hoell, A., and Michaelsen, J.: The climate hazards infrared precipitation with stations - a new environmental record for monitoring extremes, Sci. Data, 2, 150066, https://doi.org/10.1038/sdata.2015.66, 2015.

Garcia, M., Raes, D., and Jacobsen, S.-E.: Evapotranspiration analysis and irrigation requirements of quinoa (Chenopodium quinoa) in the Bolivian highlands, Agr. Water Manage., 60, 119134, https://doi.org/10.1016/S0378-3774(02)00162-2, 2003.

Garcia, M., Raes, D., Jacobsen, S. E., and Michel, T.: Agroclimatic constraints for rainfed agriculture in the Bolivian Altiplano, J. Arid Environ., 71, 109-121, https://doi.org/10.1016/j.jaridenv.2007.02.005, 2007.

Garcia, M., Condori, B., and Del Castillo, C.: Agroecological and agronomic cultural practices of quinoa in South America, in: Quinoa: Improvement and Sustainable Production, edited by: Murphy, K. and Matanguihan, J., John Wiley \& Sons. Inc., Hoboken, USA, 25-46, ISBN 978-1-118-62805-8, 2015.

Garcia, M. and Alavi, G.: Bolivia, in: Atlas de Sequía de América Latina y el Caribe, edited by: Núñez Cobo, J. and Verbist, K., UNESCO y CAZALAC, La Serena, Chile, 29-42, 2018 (in Spanish).

Garreaud, R., Vuille, M., and Clement, A. C.: The climate of the Altiplano: observed current conditions and mechanisms of past changes, Palaeogeogr. Palaeocl., 194, 5-22, https://doi.org/10.1016/S0031-0182(03)00269-4, 2003.

Garreaud, R. D. and Aceituno, P.: Interannual rainfall variability over the South American Altiplano, J. Climate, 14, 2779-2789, https://doi.org/10.1175/15200442(2001)014<2779:Irvots>2.0.Co;2, 2001.

Geerts, S., Raes, D., Garcia, M., Mendoza, J., and Huanca, R.: Crop water use indicators to quantify the flexible phenology of quinoa (Chenopodium quinoa Willd.) in re- sponse to drought stress, Field Crops Res., 108, 150-156, https://doi.org/10.1016/j.fcr.2008.04.008, 2008.

Geerts, S., Raes, D., Garcia, M., Miranda, R., Cusicanqui, J. A., Taboada, C., Mendoza, J., Huanca, R., Mamani, A., Condori, O., Mamani, J., Morales, B., Osco, V., and Steduto, P.: Simulating Yield Response of Quinoa to Water Availability with AquaCrop, Agron. J., 101, 499-508, https://doi.org/10.2134/agronj2008.0137s, 2009.

Helman, D., Givati, A., and Lensky, I. M.: Annual evapotranspiration retrieved from satellite vegetation indices for the eastern Mediterranean at $250 \mathrm{~m}$ spatial resolution, Atmos. Chem. Phys., 15, 12567-12579, https://doi.org/10.5194/acp-15-125672015, 2015.

Holben, B. N.: Characteristics of maximum-value composite images from temporal AVHRR data, Int. J. Remote Sens., 7, 14171434, https://doi.org/10.1080/01431168608948945, 1986.

Huang, M., Piao, S., Ciais, P., Peñuelas, J., Wang, X., Keenan, T. F., Peng, S., Berry, J. A., Wang, K., Mao, J., Alkama, R., Cescatti, A., Cuntz, M., De Deurwaerder, H., Gao, M., He, Y., Liu, Y., Luo, Y., Myneni, R. B., Niu, S., Shi, X., Yuan, W., Verbeeck, H., Wang, T., Wu, J., and Janssens, I. A.: Air temperature optima of vegetation productivity across global biomes, Nat. Ecol. Evol., 3, 772-779, https://doi.org/10.1038/s41559-019-0838-x, 2019.

Iizumi, T., Luo, J.-J., Challinor, A. J., Sakurai, G., Yokozawa, M., Sakuma, H., Brown, M. E., and Yamagata, T.: Impacts of El Niño Southern Oscillation on the global yields of major crops, Nat. Commun., 5, 3712, https://doi.org/10.1038/ncomms4712, 2014.

INE: Censo Agropecuario de Bolivia 2013, first ed., The National Institute of Statistics (INE) of Bolivia, La Paz, 143 pp., 2015 (in Spanish).

IPCC: Managing the Risks of Extreme Events and Disasters to Advance Climate Change Adaptation. A Special Report of Working Groups I and II of the Intergovernmental Panel on Climate Change, Cambridge University Press, Cambridge, UK and New York, USA, 582, 2012.

IPCC: Climate Change 2013: The Physical Science Basis. Contribution of Working Group I to the Fifth Assessment Report of the Intergovernmental Panel on Climate Change, edited by: Stocker, T. F., Qin, D., Plattner, G.-K., Tignor, M., Allen, S. K., Boschung, J., Nauels, A., Xia, Y., Bex, V., and Midgley, G. F., Cambridge University Press, Cambridge, United Kingdom and New York, NY, USA, 1535 pp., 2013.

Ji, L. and Peters, A. J.: Assessing vegetation response to drought in the northern Great Plains using vegetation and drought indices, Remote Sens. Environ., 87, 85-98, https://doi.org/10.1016/S0034-4257(03)00174-3, 2003.

Karnieli, A., Agam, N., Pinker, R. T., Anderson, M., Imhoff, M. L., Gutman, G. G., Panov, N., and Goldberg, A.: Use of NDVI and Land Surface Temperature for Drought Assessment: Merits and Limitations, J. Climate, 23, 618-633, https://doi.org/10.1175/2009jcli2900.1, 2010.

Kogan, F. and Guo, W.: Strong 2015-2016 El Niño and implication to global ecosystems from space data, Int. J. Remote Sens., 38, 161-178, https://doi.org/10.1080/01431161.2016.1259679, 2017.

Kogan, F. N.: Application of vegetation index and brightness temperature for drought detection, Adv. Space Res., 15, 91-100, https://doi.org/10.1016/0273-1177(95)00079-T, 1995. 
Kogan, F. N.: Satellite-Observed Sensitivity of World Land Ecosystems to El Niño/La Niña, Remote Sens. Environ., 74, 445-462, https://doi.org/10.1016/S0034-4257(00)00137-1, 2000.

Kutner, M. H., Nachtsheim, C. J., and Neter, J.: Applied linear regression models, forth ed., McGraw-Hill/Irwin Series: Operations and decision sciences, Ohio, US, 701 pp., ISBN 978$0073014661,2004$.

Legates, D. R. and Willmott, C. J.: Mean seasonal and spatial variability in gauge-corrected, global precipitation, Int. J. Climatol., 10, 111-127, https://doi.org/10.1002/joc.3370100202, 1990a.

Legates, D. R. and Willmott, C. J.: Mean seasonal and spatial variability in global surface air temperature, Theor. Appl. Climatol., 41, 11-21, https://doi.org/10.1007/BF00866198, 1990b.

Moran, M. S., Clarke, T. R., Inoue, Y., and Vidal, A.: Estimating crop water deficit using the relation between surface-air temperature and spectral vegetation index, Remote Sens. Environ., 49, 246-263, https://doi.org/10.1016/0034-4257(94)90020-5, 1994.

Null, J.: El Niño and La Niña Years and Intensities, available at: https://ggweather.com/enso/oni.htm (last access: 11 February 2020), 2018.

Ochoa, A., Pineda, L., Crespo, P., and Willems, P.: Evaluation of TRMM 3B42 precipitation estimates and WRF retrospective precipitation simulation over the Pacific-Andean region of Ecuador and Peru, Hydrol. Earth Syst. Sci., 18, 3179-3193, https://doi.org/10.5194/hess-18-3179-2014, 2014.

Ottlé, C. and Vidal-Madjar, D.: Estimation of land surface temperature with NOAA9 data, Remote Sens. Environ., 40, 27-41, https://doi.org/10.1016/0034-4257(92)90124-3, 1992.

Paredes-Trejo, F. J., Álvarez Barbosa, H., Peñaloza-Murillo, M. A., Moreno, M. A., and Farias, A.: Intercomparison of improved satellite rainfall estimation with CHIRPS gridded product and rain gauge data over Venezuela, Atmosphere, 29, 323-342, https://doi.org/10.20937/atm.2016.29.04.04, 2016.

Paredes-Trejo, F. J., Barbosa, H. A., and Lakshmi Kumar, T. V.: Validating CHIRPS-based satellite precipitation estimates in Northeast Brazil, J. Arid Environ., 139, 26-40, https://doi.org/10.1016/j.jaridenv.2016.12.009, 2017.

Pinzon, J. E. and Tucker, C. J.: NDVI: Normalized Difference Vegetation Index-3rd generation using GIMMS from AVHRR sensors, Retrieved from Climate Data Guide, edited by: National Center for Atmospheric Research Staff, available at: https://climatedataguide.ucar.edu/climate-data/ndvi-normalizeddifference-vegetation-index-3rd-generation-nasagfsc-gimms (last access: 19 July 2020), 2018.

Quiroz, R., Yarlequé, C., Posadas, A., Mares, V., and Immerzeel, W. W.: Improving daily rainfall estimation from NDVI using a wavelet transform, Environ. Model. Softw., 26, 201-209, https://doi.org/10.1016/j.envsoft.2010.07.006, 2011.

Ramirez-Rodrigues, M. A., Asseng, S., Fraisse, C., Stefanova, L., and Eisenkolbi, A.: Tailoring wheat management to ENSO phases for increased wheat production in Paraguay, Climate Risk Management, 3, 24-38, https://doi.org/10.1016/j.crm.2014.06.001, 2014.

Rencher, A. C.: Methods of Multivariate Analysis, John Wiley \& Sons, New York, 1995.

Rivera, J. A., Marianetti, G., and Hinrichs, S.: Validation of CHIRPS precipitation dataset along the Central Andes of Argentina, Atmos. Res., 213, 437-449, https://doi.org/10.1016/j.atmosres.2018.06.023, 2018.
Rodell, M., Houser, P. R., Jambor, U., Gottschalck, J., Mitchell, K., Meng, C.-J., Arsenault, K., Cosgrove, B., Radakovich, J., Bosilovich, M., Entin, J. K., Walker, J. P., Lohmann, D., and Toll, D.: The Global Land Data Assimilation System, B. Am. Meteor. Soc., 85, 381-394, https://doi.org/10.1175/bams-85-3-381, 2004.

Sánchez, N., Martínez-Fernández, J., González-Piqueras, J., González-Dugo, M. P., Baroncini-Turrichia, G., Torres, E., Calera, A., and Pérez-Gutiérrez, C.: Water balance at plot scale for soil moisture estimation using vegetation parameters, Agr. Forest Meteor., 166-167, 1-9, https://doi.org/10.1016/j.agrformet.2012.07.005, 2012.

Santos, J. L.: The Impact of El Niño - Southern Oscillation Events on South America, Adv. Geosci., 6, 221-225, https://doi.org/10.5194/adgeo-6-221-2006, 2006.

Santoso, A., Hendon, H., Watkins, A., Power, S., Dommenget, D., England, M. H., Frankcombe, L., Holbrook, N. J., Holmes, R., Hope, P., Lim, E.-P., Luo, J.-J., McGregor, S., Neske, S., Nguyen, H., Pepler, A., Rashid, H., Gupta, A. S., Taschetto, A. S., Wang, G., Abellán, E., Sullivan, A., Huguenin, M. F., Gamble, F., and Delage, F.: Dynamics and Predictability of El Niño-Southern Oscillation: An Australian Perspective on Progress and Challenges, B. Am. Meteor. Soc., 100, 403-420, https://doi.org/10.1175/bams-d-18-0057.1, 2019.

Satgé, F., Bonnet, M.-P., Gosset, M., Molina, J., Hernan Yuque Lima, W., Pillco Zolá, R., Timouk, F., and Garnier, J.: Assessment of satellite rainfall products over the Andean plateau, Atmos. Res., 167, 1-14, https://doi.org/10.1016/j.atmosres.2015.07.012, 2016.

SENAMHI: Sismet, gauged precipitation and temperature monthly datasets, Servicio Nacional de Meteorología e Hidrología (SENAMHI) de Bolivia, available at: http://senamhi.gob.bo/ index.php/sismet, last access: 15 September 2019 (in Spanish).

Shinoda, M.: Seasonal phase lag between rainfall and vegetation activity in tropical Africa as revealed by NOAA satellite data, Int. J. Climatol., 15, 639-656, https://doi.org/10.1002/joc.3370150605, 1995.

Thibeault, J., Seth, A., and Wang, G. L.: Mechanisms of summertime precipitation variability in the Bolivian Altiplano: present and future, Int. J. Climatol., 32, 2033-2041, https://doi.org/10.1002/joc.2424, 2012.

Thompson, L. G., Mosley-Thompson, E., and Arnao, B. M.: El Niño-Southern Oscillation events recorded in the stratigraphy of the tropical Quelccaya ice cap, Peru, Science, 226, 50-53, https://doi.org/10.1126/science.226.4670.50, 1984.

Tippett, M. K., Barnston, A. G., and Li, S.: Performance of Recent Multimodel ENSO Forecasts, J. Appl. Meteorol. Clim., 51, 637654, https://doi.org/10.1175/jamc-d-11-093.1, 2012.

UNDP: Tras las huellas del cambio climático en Bolivia. Estado del arte del conocimiento sobre adaptación al cambio climático: agua y seguridad alimentaria, UNDP-Bolivia, La Paz, Bolivia, 144 pp., 2011 (in Spanish).

UNEP: Diagnostico Ambiental del Sistema Titicaca-DesaguaderoPoopo-Salar de Coipasa (Sistema TDPS) Bolivia - Perú, United Nations Environment Programme (UNEP), Washington, D.C., 1996 (in Spanish).

UNISDR: Drought Risk Reduction Framework and Practices: Contributing to the Implementation of the Hyogo Framework for Ac- 
tion, United Nations secretariat of the International Strategy for Disaster Reduction (UNISDR), Geneva, Switzerland, 2009.

UNISDR: Making Development Sustainable: The Future of Disaster Risk Management, Global Assessment Report on Disaster Risk Reduction, United Nations Office for Disaster Risk Reduction (UNISDR), Geneva, Switzerland, 2015.

van Loon, C. D.: The effect of water stress on potato growth, development, and yield, Am. Potato J., 58, 51-69, https://doi.org/10.1007/BF02855380, 1981.

Verbist, K., Amani, A., Mishra, A., and Cisneros, B. J.: Strengthening drought risk management and policy: UNESCO International Hydrological Programme's case studies from Africa and Latin America and the Caribbean, Water Policy, 18, 245-261, https://doi.org/10.2166/wp.2016.223, 2016.

Vicente-Serrano, S. M., Chura, O., López-Moreno, J. I., AzorinMolina, C., Sanchez-Lorenzo, A., Aguilar, E., Moran-Tejeda, E., Trujillo, F., Martínez, R., and Nieto, J. J.: Spatio-temporal variability of droughts in Bolivia: 1955-2012, Int. J. Climatol., 35, 3024-3040, https://doi.org/10.1002/joc.4190, 2015.

Vuille, M.: Atmospheric circulation over the Bolivian Altiplan10.1175/1520-0493(1988)1o during dry and wet periods and extreme phases of the Southern Oscillation, Int. J. Climatol., 19, 1579-1600, https://doi.org/10.1002/(SICI)10970088(19991130)19:14<1579::AID-JOC441>3.0.CO;2-N, 1999.

Wilhite, D. A. and Glantz, M. H.: Understanding: The Drought Phenomenon: The Role of Definitions, in: Planning for Drought: Toward a Reduction of Social Vulnerability, edited by: Wilhite, D. A., Easterling, W. E., and Wood, D. A., Westview Press, Boulder, USA, 10-30, 1985.
Wilks, D. S.: Statistical Methods in the Atmospheric Sciences, second ed., Academic Press, Oxford, UK, 648 pp., 2006.

Willmott, C. J. and Matsuura, K.: Smart Interpolation of Annually Averaged Air Temperature in the United States, J. Appl. Meteorol., 34, 2577-2586, https://doi.org/10.1175/15200450(1995)034<2577:sioaaa>2.0.co;2, 1995.

Willmott, C. J. and Matsuura, K.: Terrestrial Air Temperature and Precipitation: Monthly and Annual Time Series 1950-1999 provided by the NOAA/OAR/ESRL PSL, Boulder, Colorado, USA, available at: https://psl.noaa.gov/data/gridded/data.UDel_AirT_ Precip.html (last access: 1 May 2020), 2001.

Yarleque, C., Vuille, M., Hardy, D. R., Posadas, A., and Quiroz, R.: Multiscale assessment of spatial precipitation variability over complex mountain terrain using a high-resolution spatiotemporal wavelet reconstruction method, J. Geophys. Res.-Atmos., 121, 12198-12216, https://doi.org/10.1002/2016jd025647, 2016.

Zhou, J. and Lau, K.-M.: Does a monsoon climate exist over South America?, J. Climate, 11, 1020-1040, https://doi.org/10.1175/15200442(1998)011<1020:damceo>2.0.co;2, 1998. 